\title{
Determination of effector molecules in L-arabinose-induced bulge formation and lysis of Escherichia coli IFO 3545
}

\author{
Toshio Tanaka, ${ }^{*}$ Hisae Muroi, Chikao Sunada, Makoto Taniguchi and Susumu Oi \\ Department of Biology, Faculty of Science, Osaka City University, Sugimoto 3-3-138, Sumiyoshi-ku, Osaka 558, Japan
}

(Received 6 September 1990; revised 2 January 1991; accepted 2 January 1991)

\begin{abstract}
L-Ribulose 5-phosphate (L-Ru5P) was identified as the primary effector molecule of L-arabinose-induced bulge formation in Escherichia coli IFO 3545 observed in nutrient broth with $5 \%$ (w/v) sodium chloride. Hyperinduction of $L$-arabinose isomerase was due to exogenous sodium chloride and the resulting alteration in the balance of the $L$ arabinose-metabolizing enzymes resulted in accumulation of L-Ru5P. L-Ru5P induced the lysis of an L-arabinosenegative, L-Ru5P 4-epimerase-less mutant, ara-207, even when directly added to the medium but was not active against the wild-type strain. Some $L$-arabinose-utilizing (L-arabinose-resistant) revertants of ara-207 were still sensitive to L-Ru5P, indicating the involvement of another mutation in L-Ru5P-sensitivity other than genetic lack of L-Ru5P 4-epimerase. Among the various pentose phosphate esters tested, only L-Ru5P could induce lysis of ara-207. The lytic activity of L-Ru5P was attributed to its effect on bacterial sugar nucleotide metabolism which caused secondary accumulation of uridine $5^{\prime}$-diphosphate galactose (UDPGal), which provoked lysis induction.
\end{abstract}

\section{Introduction}

L-Arabinose can induce the characteristic morphological change of bulge formation, highly reminiscent of a penicillin-induced bulge (Schwarz et al., 1969; Spratt, 1975), in Escherichia coli IFO 3545 grown under hypertonic condition with $5 \%(\mathrm{w} / \mathrm{v})$ sodium chloride (Tanaka et al., 1986). Bulge formation was observed in mutant ara-207, defective for L-ribulose 5-phosphate ( $\mathrm{L}$ Ru5P) 4-epimerase, in the absence of sodium chloride but not in mutants defective for either L-arabinose isomerase or L-ribulokinase (Tanaka et al., 1988a). These findings strongly suggested that osmotic treatment of $E$. coli cells with $5 \%(\mathrm{w} / \mathrm{v})$ sodium chloride could regulate the level of activity of an L-arabinose-metabolizing enzyme (i.e. repression or inhibition of L-Ru5P 4epimerase). However, it is doubtful whether environmental osmotic conditions can produce differential control of individual L-arabinose-metabolizing enzymes,

Abbreviations: L-Ru5P, L-ribulose 5-phosphate; UDPGal, uridine 5 -diphosphate galactose; PG, peptidoglycan; UDPGlcNAc, uridine 5 -diphosphate $N$-acetylglucosamine; D-Xu5P, D-xylulose 5-phosphate; D-G3P, D-glyceraldehyde 3-phosphate; D-R5P, D-ribose 5-phosphate; LPS, lipopolysaccharide; GlcNAc, $N$-acetylglucosamine; UDPG, uridine 5'-diphosphate glucose; D-Ru5P, D-ribulose 5-phosphate; D-R1P, D-ribose 1-phosphate; D-Gal1P, D-galactose 1-phosphate. since the genetic expression of such enzymes is coordinated by the same control region in the L-arabinose operon (Cleary \& Englesberg, 1974; Colomé et al., 1977; Englesberg et al., 1965). In the present study, the Larabinose-induced morphological change of $E$. coli IFO 3545 was further characterized with respect to the relationship between accumulation of an effector molecule and osmoregulation of the L-arabinose metabolizing enzymes.

Our previous study also suggested that L-Ru5P might be an effector molecule of $\mathrm{L}$-arabinose-induced morphological change and lysis through its ability to inhibit bacterial cell wall synthesis (Tanaka et al., 1988a). We applied HPLC analysis (Mengin-Lecreulx et al., 1983; Payne \& Ames, 1982) to detect peptidoglycan (PG) precursors such as uridine 5 -diphosphate $N$-acetylglucosamine (UDPGlcNAc) and its derivatives which may accumulate due to inhibition of $P G$ synthesis. Although the above substances were not detectable in abnormal quantities, HPLC analysis revealed overproduction of uridine 5 -diphosphate galactose (UDPGal) in ara-207 cells grown with L-Ru5P. The present report describes the lytic effect of L-Ru5P on ara-207 and its effect on secondary accumulation of UDPGal which is closely involved with the lytic events of $E$. coli (Yarmolinsky et al., 1959) and Salmonella sp. (Fukasawa \& Nikaido, 1961). 


\section{Methods}

Bacterial strains. Escherichia coli IFO 3545 (Tanaka et al., 1986) and its mutant with a defect in L-Ru5P 4-epimerase, ara-207 (Tanaka et al., $1988 a$ ), were used. L-Arabinose-resistant revertants of ara-207 were isolated as described below. An overnight culture $(100 \mu \mathrm{l})$ of ara-207 in $3 \% \mathrm{NB}\left(5 \mathrm{~g}\right.$ beef extract, $15 \mathrm{~g}$ polypeptone, $5 \mathrm{~g} \mathrm{~K}_{2} \mathrm{HPO}_{4} \mathrm{l}^{-1} ; \mathrm{pH} \mathrm{7.0)}$ was inoculated into $5 \mathrm{ml}$ of $1 \% \mathrm{NB}$ (the concentration of each component was one-third of that in $3 \% \mathrm{NB}$ ) containing $6.7 \mathrm{mM}-\mathrm{L}-$ arabinose and grown with shaking at $37^{\circ} \mathrm{C}$ for more than $7 \mathrm{~h}$ until complete lysis was observed. After centrifugation of the lysate at 8000 r.p.m. for $10 \mathrm{~min}$, the resulting pellet was washed with $0.8 \%$ sodium chloride and plated onto $1 \%$ NB agar containing $6.7 \mathrm{~mm}$-L-arabinose. Colonies were picked after overnight incubation at $37^{\circ} \mathrm{C}$ and considered as L-arabinose-resistant revertants of ara-207.

Media and growth conditions. Unless stated otherwise, precultivation was done with $3 \% \mathrm{NB}$ and the bacterial growth or morphological change was examined in $1 \%$ NB according to our method described previously (Tanaka et al., 1986, 1988a). Utilization of L-arabinose was examined using M-9 mineral salts medium (Tanaka et al., 1988a).

Assay of L-arabinose-metabolizing enzymes. Arabinose-metabolizing enzymes such as L-arabinose isomerase, L-ribulokinase and L-Ru5P 4epimerase were assayed as described previously (Tanaka et al., 1988a). Cells grown in hypertonic medium containing $5 \%(\mathrm{w} / \mathrm{v})$ sodium chloride were washed and resuspended in $100 \mathrm{~mm}-\mathrm{Tris} / \mathrm{HCl}$ buffer, $\mathrm{pH} 7.5$, supplemented with $5 \%(\mathrm{w} / \mathrm{v})$ sodium chloride prior to disruption by sonication. One unit of each enzyme activity was defined as the amount of enzyme that catalysed the conversion of $1 \mu \mathrm{mol}$ substrate $\min ^{-1}$ under the assay conditions.

Assay of L-arabinose metabolites. Cells of E. coli IFO 3545 (wild-type) were grown in $500 \mathrm{ml} 1 \% \mathrm{NB}$ [supplemented with or without $5 \%(\mathrm{w} / \mathrm{v})$ sodium chloride] containing $66.7 \mathrm{mM}$-L-arabinose. Samples of the bacterial cell suspension $(100 \mathrm{ml})$ were withdrawn and harvested by centrifugation at several stages of cultivation. After washing twice with $5 \%(\mathrm{w} / \mathrm{v})$ sodium chloride, cell pellets were suspended in $5 \mathrm{ml}$ distilled water. L-Arabinose metabolites were then extracted by vigorously shaking the cell suspension with $50 \mu \mathrm{l}$ toluene at $30^{\circ} \mathrm{C}$ for $15 \mathrm{~min}$. The above extraction procedure was as effective as that with trichloroacetic acid reported by Englesberg et al. (1962) and even more useful in that the supernatant obtained after removing the cell pellet could be employed directly in the following assays. Total pentose phosphate esters such as L-Ru5P and D-xylulose 5-phosphate (D-Xu5P) were colorimetrically determined by a modified $o$-aminodiphenylacetic acid method (Tanaka et al., 1988b). Enzyme coupling reactions were employed for specific determination of D-Xu5P and D-glyceraldehyde 3-phosphate (D-G3P), respectively, as described below. After heating the sample at $100^{\circ} \mathrm{C}$ for $5 \mathrm{~min}$ and removing the resulting precipitate by centrifugation, each supernatant $(1.4 \mathrm{ml})$ was incubated with a mixture of $30 \mu \mathrm{mol}$ sodium glutathione, $1.2 \mu \mathrm{mol}$ thiamin pyrophosphate, $12 \mu \mathrm{mol} \mathrm{MgCl}_{2} .6 \mathrm{H}_{2} \mathrm{O}, 1.5 \mu \mathrm{mol} \mathrm{NAD}^{+}, 12 \mu \mathrm{mol}$ D-ribose 5phosphate (D-R5P), 1 unit transketolase, and 5 units D-G3P dehydrogenase in $1.9 \mathrm{ml} 30 \mathrm{~mm}$-glycylglycine $(\mathrm{pH} 8.5)$ at $30^{\circ} \mathrm{C}$. D-G3P was measured by following the increase in absorbance at $340 \mathrm{~nm}$ in a control reaction which was run without transketolase and D-R5P. D$\mathrm{Xu} 5 \mathrm{P}$ was measured from the difference in absorbances at $340 \mathrm{~nm}$ obtained in the above two reactions. In the present study, total pentose phosphate esters detected during L-arabinose metabolism were found to consist mainly of L-Ru5P; the amount of D-Xu5P measured enzymically was negligible. L-Arabinose was determined according to the method of Timell et al. (1956). Thin-layer chromatography was performed using silica gel plates (Merck Kieselgel 60) and butanol/propionic acid/water (10:5:7, by vol.) as the solvent. After development twice at room temperature, sugar phosphate esters were located by spraying with a mixture consisting of $5 \mathrm{ml} 60 \%(\mathrm{v} / \mathrm{v})$ perchloric acid,

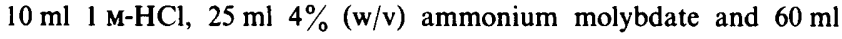
distilled water, followed by heating at $100^{\circ} \mathrm{C}$ and ultraviolet irradiation.

Incorporation of radioactive precursors into macromolecular cell wall fractions. An overnight culture of wild-type strain or ara-207 $(100 \mu \mathrm{l})$ was inoculated into $5 \mathrm{ml} 1 \% \mathrm{NB}$ and grown with shaking at $30^{\circ} \mathrm{C}$. For the assay of lipopolysaccharide (LPS) synthesis, D- $\left[1-{ }^{14} \mathrm{C}\right]$ galactose $\left(50 \mathrm{mCi} \mathrm{mmol}^{-1} ; 1.85 \mathrm{GBq} \mathrm{mmol}^{-1}\right)$ was added to a final activity of $0.5 \mu \mathrm{Ci} \mathrm{ml}^{-1}$ to the growing culture at an $\mathrm{OD}_{660}$ of $0 \cdot 1$. Cell samples $(200 \mu \mathrm{l})$ were withdrawn at $5 \mathrm{~min}$ intervals and poured into $1 \mathrm{ml}$ cold $1.32 \mathrm{M}-\mathrm{NH}_{4} \mathrm{OH}$ containing $6.6 \mathrm{~mm}-\mathrm{MgCl}_{2}$. Alkali-insoluble precipitates were collected on glass microfibre filters (Whatman GF/C) and radioactivity on the filters was counted with $10 \mathrm{ml}$ toluene-based scintillation fluid in a Packard Tri-Carb 460 scintillation counter as reported by Ichimura et al. (1987). $\mathrm{N}$-Acetyl[ $\left[1^{-14} \mathrm{C}\right]$ glucosamine ([1$\left.\left.{ }^{14} \mathrm{C}\right] \mathrm{GlcNAc}\right)\left(50 \mathrm{mCi} \mathrm{mmol}^{-1} ; 1.85 \mathrm{GBq} \mathrm{mmol}^{-1}\right)$ was added to a final activity of $0.05 \mu \mathrm{Ci} \mathrm{ml}^{-1}$ as the precursor of both PG and LPS synthesis. Cell samples $(200 \mu \mathrm{l})$ were withdrawn and poured into $1 \mathrm{ml}$ cold $10 \%(\mathrm{w} / \mathrm{v})$ trichloroacetic acid, and then acid-insoluble precipitates were collected and their radioactivity measured according to the above method.

Assay of intracellular level of UDPGal and uridine 5'-diphosphate glucose (UDPG). Overnight cultures ( $1 \mathrm{ml}$ each) of the wild-type strain and ara-207 as well as several L-arabinose-resistant revertants of ara207 were inoculated into $50 \mathrm{ml}$ portions of $1 \%$ NB supplemented or not with $2 \mathrm{mM}-\mathrm{L}-\mathrm{Ru} 5 \mathrm{P}$ and then grown with shaking at $30^{\circ} \mathrm{C}$ for $4 \mathrm{~h}$. Cells were harvested by centrifugation and suspended in $1 \mathrm{ml}$ distilled water. The supernatant obtained after shaking the cell suspension with $20 \mu \mathrm{l}$ toluene at $30^{\circ} \mathrm{C}$ for $15 \mathrm{~min}$ and removing the cell debris by centrifugation was analysed for its content of UDPGal and UDPG by HPLC on an ODS reverse-phase column $(6 \times 150 \mathrm{~mm})$. The operating conditions were as follows: isocratic elution at room temperature with $0.6 \mathrm{M}-\left(\mathrm{NH}_{4}\right) \mathrm{H}_{2} \mathrm{PO}_{4}$; flow rate, $1 \mathrm{ml} \mathrm{min}{ }^{-1}$; detector sensitivity at $260 \mathrm{~nm}, 0.02$ AUFS.

Chemicals. L-Arabinose was purchased from Wako Pure Chemical Co. (Japan). L-Ribulose was prepared by chemical isomerization of Larabinose as described previously (Tanaka et al., 1988a). L-Ru5P was prepared by enzymic phosphorylation of L-ribulose using L-ribulokinase according to our method reported previously (Tanaka et al., 1988a). Alcohols of L-Ru5P were prepared by reduction with $\mathrm{NaBH}_{4}$ as described below. L-Ru5P $(260 \mu \mathrm{mol})$ dissolved in $1 \mathrm{ml}$ distilled water was incubated with $5 \mathrm{ml} 0.1 \% \mathrm{NaBH}_{4}$ overnight at $25^{\circ} \mathrm{C}$. Amberlite IR 120 resin $\left(\mathrm{H}^{+}\right)$was added to decompose excess $\mathrm{NaBH}_{4}$ and the supernatant obtained after removing the resin was evaporated to dryness. The resulting precipitate was dissolved in methanol and repeatedly evaporated with methanol in vacuo. The final syrup was used as a mixture of L-arabitol 5-phosphate and L-ribitol 5-phosphate. This preparation displayed no reducing power in the reaction with Fehling's solution, indicating complete reduction of carbonyl groups. L-Arabitol and a mixture of L-arabitol and L-ribitol were prepared following the same method, using L-arabinose and L-ribulose, respectively. The following chemicals and enzymes were purchased from Sigma: D-ribulose 5-phosphate (D-Ru5P), D-Xu5P, D-R5P, D-G3P, D-ribose 1-phosphate (D-R1P), transketolase and D-G3P dehydrogenase. D- $\left[1^{-14} \mathrm{C}\right]$ Galactose $\left(50 \mathrm{mCi} \mathrm{mmol}^{-1}\right)$ and $\left[1^{-14} \mathrm{C}\right] \mathrm{GlcNAc}(50 \mathrm{mCi}$ $\mathrm{mmol}^{-1}$ ) were products of American Radiolabelled Chemicals Inc.

\section{Results}

Effect of sodium chloride on L-arabinose metabolism

An L-arabinose-induced morphological change was first observed in the $E$. coli IFO 3545 wild-type strain along 


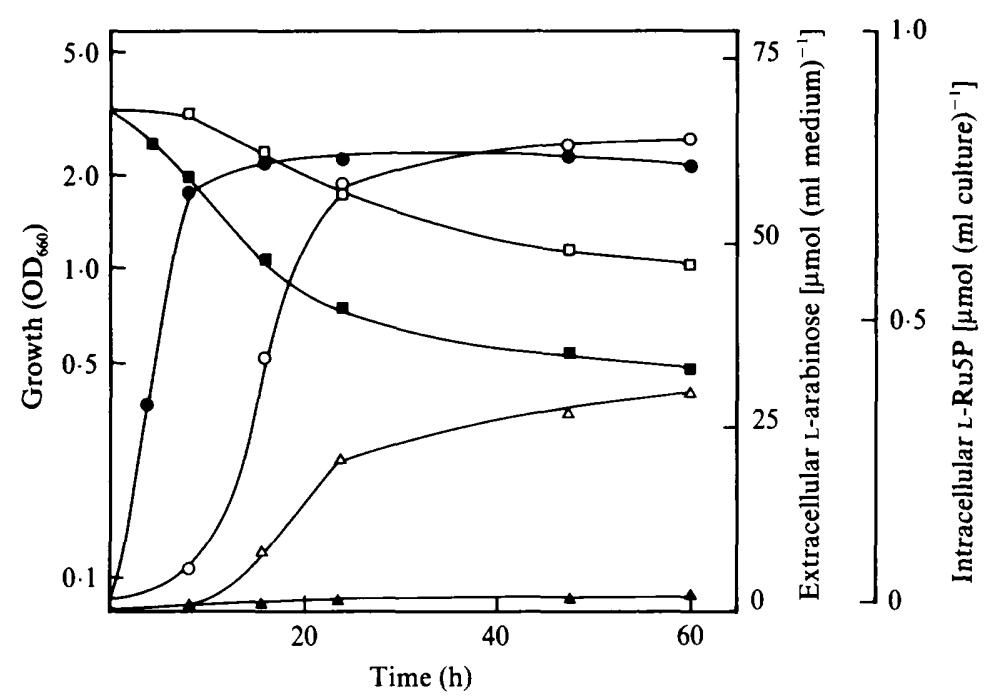

Fig. 1. Course of L-arabinose metabolism in $E$. coli IFO 3545 wild-type strain grown at $30^{\circ} \mathrm{C}$ in $500 \mathrm{ml}$ of $1 \%$ NB containing $66.7 \mathrm{mM}$-L-arabinose in the presence (open symbols) or absence (filled symbols) of $5 \%(\mathrm{w} / \mathrm{v})$ sodium chloride. At the times indicated, cell suspensions were withdrawn and used for assays of growth $(\mathrm{O}, \mathrm{O})$, L-arabinose remaining in the medium $(\square, \square)$ and L-Ru5P accumulated in the cells $(\triangle, \Delta)$, as described in the text. The amounts of $L$ Ru5P are expressed as total pentose phosphate esters detected in the extracts of toluene-treated cells obtained from $1 \mathrm{ml}$ culture. with inhibition of bacterial cell division under hypertonic conditions with $5 \%(\mathrm{w} / \mathrm{v})$ sodium chloride (Tanaka et al., 1986). Under these conditions, the presence of sodium chloride was expected to affect the bacterial Larabinose metabolism so that the effector molecule accumulated within the cells. As shown in Fig. 1, a pentose phosphate ester (L-Ru5P) was detected by the modified $o$-aminodiphenylacetic acid test at a significant level during growth of the wild-type strain in $1 \% \mathrm{NB}$ containing $66.7 \mathrm{mM}-\mathrm{L}$-arabinose and $5 \%(\mathrm{w} / \mathrm{v})$ sodium chloride. An enzymic assay could detect D-Xu5P but the amount obtained from cells of $1 \mathrm{ml}$ culture was less than $5 \mathrm{nmol}$, being negligible compared to the total pentose phosphate ester. The major positive component in the colorimetric reaction assay was identified by thin-layer chromatography to be L-Ru5P. However, the amount of $\mathrm{L}-\mathrm{Ru} 5 \mathrm{P}$ detected was less than that of L-arabinose taken up from the medium. This indicated that accumulation of L-Ru5P did not depend on complete inhibition or repression of $\mathrm{L}$-arabinose metabolism as was the case for the mutant with a genetic defect in L-Ru5P 4-epimerase.

Accumulation of L-Ru5P could result from an alteration in the balance of $\mathrm{L}$-arabinose-metabolizing enzymes such as L-arabinose isomerase, L-ribulokinase and LRu5P 4-epimerase. Therefore assays were done for these enzymes using cell-free extracts at several stages of growth. In the absence of sodium chloride, the highest activities of L-arabinose isomerase, L-ribulokinase and L$\mathrm{Ru} 5 \mathrm{P}$ 4-epimerase were detected during the exponential growth phase $(4 \mathrm{~h})$ and decreased with further cultivation, as shown in Table 1. L-Arabinose isomerase was detected at an apparently higher level than the other two enzymes at $16 \mathrm{~h}$ of cultivation with $5 \%(\mathrm{w} / \mathrm{v})$ sodium chloride. The activity of this enzyme was slightly repressed at $40 \mathrm{~h}$ of cultivation but was still much higher than those of the other two enzymes. The assay could not be done for the sample from $4 \mathrm{~h}$ cultivation with $5 \%$ (w/v) sodium chloride because of poor growth. From the biochemical viewpoint, hyperinduction of L-arabinose isomerase was the most probable cause of the accumulation of L-Ru5P arising from treatment of $E$. coli with sodium chloride.

\section{Lytic effect of L-RuSP}

L-Ru5P which had accumulated intracellularly was thought to be important in the bulge formation of wildtype cells. As shown in Fig. 2, however, L-Ru5P did not show any effect on the growth and morphology of the wild-type strain when added to the medium. In contrast, lysis of the L-Ru5P 4-epimerase-less mutant, ara-207, occurred after $4 \mathrm{~h}$ of cultivation in $1 \% \mathrm{NB}$ plus L-Ru5P, as observed with its precursor, L-arabinose (Tanaka $e t$ $a l$., 1988a). The minimum concentration of L-Ru5P (2.0 mM) effective for lysis of ara-207 was lower than that of L-arabinose (6.7 mM).

Microscopical observation revealed bulged and spheroplast-like cells prior to bacterial lysis. Thus, it was concluded that L-Ru5P was an effector of bulge formation and lysis of $E$. coli cells.

\section{Sensitivity to the lytic effect of $L-R u 5 P$}

The wild-type strain was probably resistant to exogenously added L-Ru5P either because it could metabolize this compound by dephosphorylation to yield assimilable L-ribulose or via a constitutive level of L-Ru5P 4-epimerase (it is not known if L-Ru5P can serve as an inducer of the L-arabinose operon). Therefore, the relationship between L-Ru5P sensitivity and the genetic defect in L-Ru5P 4-epimerase was examined using 50 independently isolated L-arabinose-resistant revertants 


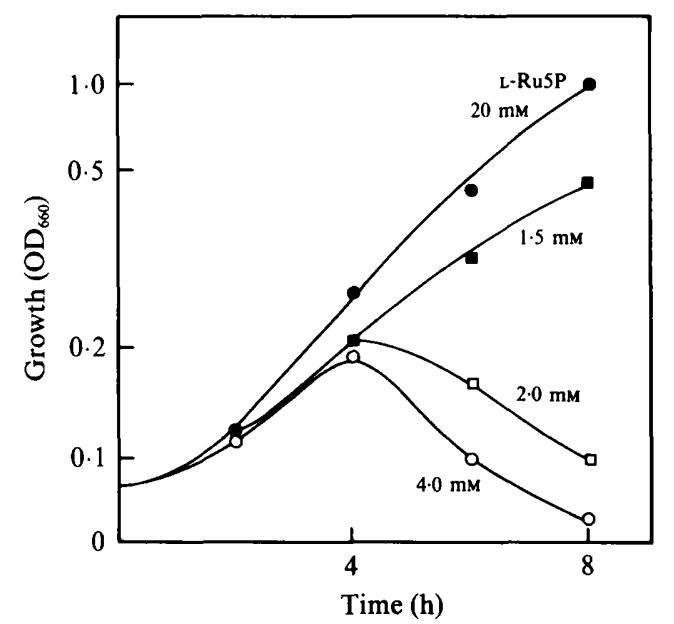

Fig. 2. Effect of L-RuSP on the growth of E. coli IFO 3545 wild-type strain $(\odot)$ and mutant ara-207 $(O, \square, \square)$. Cells were grown with shaking at $30^{\circ} \mathrm{C}$ in $5 \mathrm{ml}$ of $1 \% \mathrm{NB}$ supplemented with L-Ru5P at various concentrations.

Table 1. Levels of L-arabinose-metabolizing enzymes in E. coli IFO 3545

Cells of wild-type $E$. coli were grown in $500 \mathrm{ml}$ of $1 \%$ NB containing $66.7 \mathrm{mM}$-L-arabinose or $66.7 \mathrm{mM}$-L-arabinose and $5 \%$ sodium chloride at $30^{\circ} \mathrm{C}$. At the times indicated, samples $(100 \mathrm{ml})$ were withdrawn and enzyme activities were assayed as described in the text.

\begin{tabular}{ccccc}
\hline \hline & & \multicolumn{2}{c}{$\begin{array}{c}\text { Enzyme activity* } \\
\text { [units (mg protein) }\end{array}$} \\
\cline { 3 - 5 } $\begin{array}{c}\text { Cultivation } \\
\text { time }(\mathrm{h})\end{array}$ & $\begin{array}{c}5 \% \text { Sodium } \\
\text { chloride }\end{array}$ & Isomerase & Ribulokinase & 4-Epimerase \\
\hline 4 & - & 0.212 & 0.034 & 0.076 \\
16 & - & 0.109 & 0.031 & 0.032 \\
16 & + & 0.519 & 0.049 & 0.046 \\
40 & - & 0.046 & 0.011 & 0.016 \\
40 & + & 0.394 & 0.020 & 0.008 \\
\hline \hline
\end{tabular}

* Isomerase, L-arabinose isomerase; ribulokinase, L-ribulokinase ; 4epimerase, L-Ru5P 4-epimerase.

Table 2. Characteristics of L-arabinose-resistant revertants of ara-207

\begin{tabular}{lccr}
\hline Strain & $\begin{array}{c}\text { Utilization } \\
\text { of L-arabinose }\end{array}$ & $\begin{array}{c}\text { Specific activity } \\
\text { of L-Ru5P 4-epimerase } \\
\text { [units (mg protein) }\end{array}$ & $\begin{array}{c}\text { L-Ru5P* } \\
\text { (mM) }\end{array}$ \\
\hline Wild-type & + & 0.076 & $>20$ \\
ara-207 & - & 0.000 & 2 \\
$\operatorname{ara}^{\mathrm{r}}-1$ & + & 0.047 & $>20$ \\
ara $^{\mathrm{r}}-4$ & + & 0.047 & 2 \\
ara $^{\mathrm{r}}-18$ & + & 0.023 & $>20$ \\
$\operatorname{ara}^{\mathrm{r}}-21$ & + & 0.025 & 2 \\
\hline \hline
\end{tabular}

* Minimum concentration of L-Ru5P effective for lysis. of ara-207. All of them were found to utilize L-arabinose and thus could grow without any morphological change in $1 \% \mathrm{NB}$ supplemented with L-arabinose. Table 2 shows the intracellular levels of $\mathrm{L}$-arabinose-metabolizing enzymes in some of these revertants, indicating apparent reversion of L-Ru5P 4-epimerase activity. Interestingly, 24 revertants, including ara ${ }^{r}-4$ and $\operatorname{ara}^{r}-21$, retained the same sensitivity to L-Ru5P as ara-207, showing lysis when grown with $2 \mathrm{mM}-\mathrm{L}-\mathrm{Ru} 5 \mathrm{P}$. This indicated that the L-Ru5P sensitivity of ara-207 did not depend on a genetic lack of L-Ru5P 4-epimerase but on some mutation at a gene locus other than $a r a D$, the structural gene of the enzyme.

\section{Structure-sensitivity relationship}

We examined whether the lytic activity mediated by LRu5P on ara-207 could be observed with other sugar phosphate esters or whether it was specific for L-Ru5P. Other pentose phosphate esters such as D-Ru5P, D-R5P and D-R1P were not effective even at $20 \mathrm{mM}$, indicating the existence of stereochemical specificity in the lytic activity of L-Ru5P. After complete reduction of the carbonyl group, the resulting alcohols of L-Ru5P such as L-arabitol 5-phosphate and L-ribitol 5-phosphate still retained lytic activity at $5.0 \mathrm{~mm}$. However, the corresponding sugar alcohols lacking the phosphate moiety were inactive. The phosphate moiety was therefore considered to be essential for the lytic activity of L-Ru5P.

\section{Effect of L-RU5P on incorporation of radioactive precursors into macromolecular cell wall fractions}

We tried to determine whether the lytic activity of LRu5P was due to inhibition of PG or LPS synthesis. No clear inhibition by $2 \mathrm{mM}-\mathrm{L}-\mathrm{Ru} 5 \mathrm{P}$ could be detected in the assay for incorporation of $\left[1-{ }^{14} \mathrm{C}\right] \mathrm{GlcNAc}$ into acidinsoluble material (ara-207 incorporated approximately 6000 c.p.m. during $15 \mathrm{~min}$ incubation with or without LRu5P). L-Ru5P did, however, inhibit incorporation of D$\left[1^{-14} \mathrm{C}\right]$ galactose into LPs of ara-207, as shown in Fig. 3. Apparent L-Ru5P-induced inhibition of LPS synthesis was also observed in the wild-type strain, which was resistant to lytic activity of L-Ru5P. Inhibition of $\mathrm{D}-\left[1^{-14} \mathrm{C}\right]$ galactose incorporation seemed to depend on a decrease in the specific radioactivity of labelled UDPGal, an intermediate of LPS synthesis, rather than on the inhibition of LPS synthesis itself (see below).

\section{Effect of $L-R U 5 P$ on intracellular level of UDPGal}

The concentration of UDPGlcNAc and its derivatives was within the normal range in ara-207 cells grown with L-Ru5P. In contrast, UDPGal was detected at a higher 


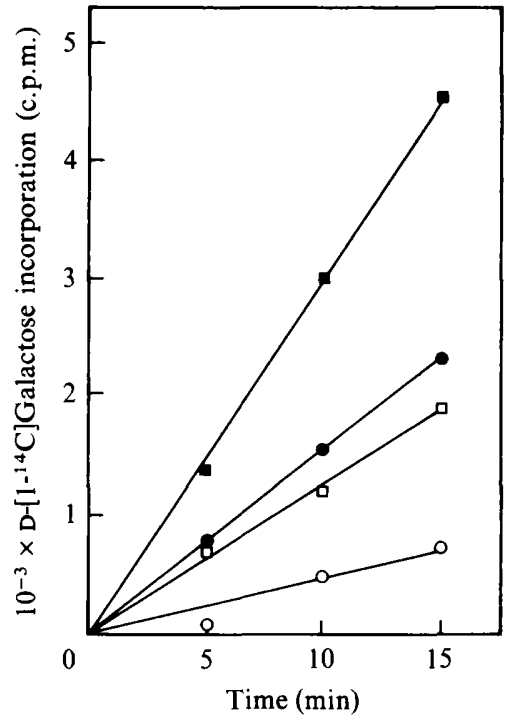

Fig. 3. Incorporation of $\mathrm{D}-\left[\mathrm{I}^{-14} \mathrm{C}\right]$ galactose into the LPS fraction of $E$. coli IFO 3545 wild-type strain $(\square, \square)$ and mutant ara-207 $(O, \bigcirc)$. The growing cultures in $1 \% \mathrm{NB}$ were supplemented with $\mathrm{D}-\left[1-{ }^{14} \mathrm{C}\right]$ galactose at $\mathrm{OD}_{660}$ of 0.1 and further incubated with (open symbols) or without (filled symbols) $2 \mathrm{~mm}-\mathrm{L}-\mathrm{Ru} 5 \mathrm{P}$ at $30^{\circ} \mathrm{C}$. At the times indicated, cell samples were withdrawn and the radioactivity in the alkali-insoluble fractions determined.

Table 3. Effect of $L-R$ SP on the level of UDPGal and $U D P G$ in several strains of E. coli IFO 3545

\begin{tabular}{lccc}
\hline \hline & & \multicolumn{2}{c}{$\begin{array}{c}\text { Intracellular level } \\
\text { [nmol (mg wet cells) }\end{array}$} \\
\cline { 3 - 4 } Strain & $\begin{array}{c}\text { Addition } \\
\text { of L-Ru5P }\end{array}$ & UDPGal & UDPG \\
\hline Wild-type & none & 0.08 & 0.08 \\
& $2 \mathrm{mM}$ & 0.04 & 0.03 \\
ara-207 & none & 0.90 & 0.03 \\
& $2 \mathrm{mM}$ & 13.50 & 0.13 \\
ara $^{\mathrm{r}}-1$ & $2 \mathrm{mM}$ & 0.13 & 0.08 \\
ara $^{\mathrm{r}-4}$ & $2 \mathrm{mM}$ & 4.59 & 0.00 \\
ara $^{\mathrm{r}}-18$ & $2 \mathrm{mM}$ & 0.04 & 0.00 \\
ara $^{\mathrm{r}}-21$ & $2 \mathrm{mM}$ & 2.26 & 0.00 \\
\hline \hline
\end{tabular}

level in ara-207 than in wild-type cells and the level was significantly higher when the cells were grown with $2 \mathrm{mM}-\mathrm{L}-\mathrm{Ru} 5 \mathrm{P}$, as shown in Table 3. Overproduction of UDPGal was also observed in revertants of ara-207 with

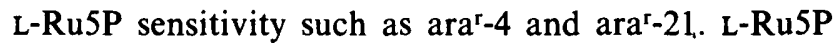
did not, however, affect the level of UDPGal in the wildtype strain, as in $\operatorname{ara}^{\mathrm{r}}-1$ and $\operatorname{ara}^{\mathrm{r}}-18$, which were resistant to the lytic activity of L-Ru5P. UDPG 4-epimerase-less mutants of E. coli K12 (Yarmolinsky et al., 1959) and Salmonella sp. (Fukasawa \& Nikaido, 1961) can accumulate UDPGal when grown with D-galactose, and UDPGal plays an essential role in D-galactose-induced lysis of these mutant strains. The lytic activity of L-RuSP on ara-207 could be attributed to its effect on another pathway of UDPGal synthesis involving epimerization of UDPG, hence causing overproduction of UDPGal.

The apparent rate of LPS synthesis decreased in response to dilution of labelled UDPGal formed from D$\left[1-^{-14} \mathrm{C}\right]$ galactose, when unlabelled UDPGal was provided. This finding suggested that UDPGal was also involved in L-arabinose-induced bulge formation of wildtype cells under hypertonic conditions with $5 \%(\mathrm{w} / \mathrm{v})$ sodium chloride. Thus, the cellular UDPGal level was examined in bulged cells of the wild-type strain obtained at $48 \mathrm{~h}$ of cultivation, when L-Ru5P was detected at almost the maximum level (Fig. 1). Unexpectedly, HPLC analysis did not reveal accumulation of a detectable amount of UDPGal. UDPGal might be further metabolized to a compound more closely involved with the morphological change of $E$. coli cells under the above conditions.

\section{Discussion}

In E. coli, L-arabinose metabolism proceeds via the reactions of $\mathrm{L}$-arabinose isomerase, $\mathrm{L}$-ribulokinase and $\mathrm{L}$ Ru5P 4-epimerase. The structural genes of these enzymes $(\operatorname{ara} B A D)$ constitute a typical gene cluster which functions as an operon, and their expression is coordinated by the $a r a C$ gene product (Lobell \& Schleif, 1990). In the present study, osmotic treatment of $E$. coli cells with $5 \%(\mathrm{w} / \mathrm{v})$ sodium chloride was found to maintain the fully induced level of L-arabinose isomerase when both Lribulokinase and L-Ru5P 4-epimerase were repressed. Missense mutations of $\operatorname{ar} a B$ coding for L-ribulokinase have been known to result in hyperinducibility of Larabinose isomerase coded for by the adjacent gene $a \mathrm{raA}$ (Katz \& Englesberg, 1971). The fully induced level of this enzyme is believed to depend on relief of self catabolite repression due to lack of L-arabinose metabolites as catabolite repressors. In support of this, we have isolated an L-arabinose-negative mutant of $E$. coli IFO 3545 ( $a r a B$ ) showing hyperinducibility of L-arabinose isomerase (Tanaka et al., 1988 a). However, the osmoregulation of an individual L-arabinose-metabolizing enzyme could not be explained simply by an effect on transcriptional control in the above mutant cells. As shown in Table 1, self catabolite repression was apparently functioning for both L-ribulokinase and L-Ru5P 4-epimerase in the presence of $5 \%(\mathrm{w} / \mathrm{v})$ sodium chloride. A post-translational change, such as alteration in its turnover, may therefore be involved in sodium chloride-hyperinduction of $L$-arabinose isomerase in wild-type cells.

Accumulation of L-Ru5P may depend on either a specific increase in the rate of its formation or a decrease in the rate of its epimerization to D-Xu5P. Our data 
support the former idea, as follows. The fully induced level of L-arabinose isomerase contributed to the activation of L-ribulokinase by providing excess Lribulose. The rate of L-Ru5P synthesis in vivo may be higher than expected from the activity of L-ribulokinase detected in the in vitro assay. Similarly, treatment of $E$. coli with sodium chloride causes an increase in the cellular ATP content, another substrate for L-Ru5P synthesis by L-ribulokinase (Ohwada \& Sagisaka, 1987).

Sugar phosphate esters such as D-GallP and L-Ru5P are known to have other biological effects via exogenous administration of their precursors. In human galactosaemia, D-GallP can cause serious pathological effects due to genetic lack of D-GallP uridylyltransferase (Schwarz et al., 1956). D-GallP is also known as an effector molecule of D-galactose-induced stasis of $E$. coli $\mathrm{K} 12$ with a genetic lack of the same enzyme (Kalckar et al., 1959; Sundararajan, 1963; Yarmolinsky et al., 1959) as is L-Ru5P in L-arabinose-induced stasis of $E$. coli $\mathrm{B} / \mathrm{r}$ deficient in L-Ru5P 4-epimerase (Englesberg et al., 1962). In the present work, the lytic effect of L-Ru5P was demonstrated when it was given to an L-Ru5P 4epimerase deficient mutant, ara-207, of E. coli IFO 3545. It should be noted that the L-Ru5P sensitivity of ara-207 did not depend on a genetic lack of L-Ru5P 4-epimerase involved in the metabolism of L-Ru5P to D-Xu5P (Table 2). The L-Ru5P-induced growth inhibition in ara-207 was rather similar to the type of D-galactose sensitivity or D-galactose-induced bacteriolysis found in $E$. coli $\mathrm{K} 12$ and Salmonella sp. deficient in UDPG 4-epimerase (Yarmolinsky et al., 1959; Fukasawa \& Nikaido, 1961). A morphological change, resembling spheroplast formation, was found for the above mutant strains during intracellular accumulation of UDPGal. L-Ru5P-induced lysis of ara-207 was also accompanied by overproduction of UDPGal but differed from D-galactose-induced lysis by the formation of bulge(s) in a typical rod cell prior to the appearance of spheroplast-like cells and lysis (Tanaka et al. 1988a). In addition, UDPGal was not detectable during $\mathrm{L}$-arabinose-induced bulge formation of wild-type cells, which occurred without apparent lysis or loss of turbidity (Fig. 1; Tanaka et al., 1986). Bulge formation may be a morphological change specifically induced by L-Ru5P, being independent of the lytic process due to accumulation of UDPGal. Fukasawa \& Nikaido (1961) investigated the mechanism of Dgalactose (UDPGal)-induced lysis of Salmonella sp. by analysing the incorporation of hexosamine and diaminopimelic acid as the major components of PG. They reported that no inhibition of PG synthesis was observed at least up to 5-10 min before lysis. No explanation has yet been found for the relationship between accumulation of UDPGal and the accompanying bacteriolysis of E. coli K12 and Salmonella sp.
UDPGal synthesis can occur via UDPG pyrophosphorylase, which yields UDPG from UTP and D-glucose 1-phosphate, and UDPG 4-epimerase in the absence of D-galactose. The data of Fig. 3 are consistent with elevated levels of UDPGal, derived from this alternative pathway, accounting for the depressed rates of incorporation into LPS of exogenous labelled galactose.

\section{References}

Cleary, P. P. \& Englesberg, E. (1974). Transcriptional control in the L-arabinose operon of Escherichia coli B/r. Journal of Bacteriology 118, $121-128$

Colomé, J., Wilcox, G. \& Englesberg, E. (1977). Constitutive mutations in the controlling site region of the $\operatorname{araBAD}$ operon of Escherichia coli $\mathrm{B} / \mathrm{r}$ that decrease sensitivity to catabolite repression. Journal of Bacteriology 129, 948-958.

Englesberg, E., Anderson, R. L., Weinberg, R., Lee, N., Hoffee, P., Huttenhauer, G. \& Boyer, H. (1962). L-Arabinose-sensitive, Lribulose-5-phosphate 4-epimerase-deficient mutant of Escherichia coli. Journal of Bacteriology 84, 137-146.

Englesberg, E., IrR, J., Power, J. \& LeE, N. (1965). Positive control of enzyme synthesis by gene $\mathrm{C}$ in the $\mathrm{L}$-arabinose system. Journal of Bacteriology 90, 946-957.

Fukasawa, T. \& NikaIDO, H. (1961). Galactose-sensitive mutants of Salmonella. II. Bacteriolysis induced by galactose. Biochimica et Biophysica Acta 48, 470-483.

Ichimura, M., Toguchi, T., Yasuzawa, T. \& Tomita, F. (1987). CV-I, a new antibiotic produced by a strain of Streptomyces sp. I. Fermentation, isolation and biological properties of the antibiotic. Journal of Antibiotics 40, 723-726.

Kalckar, H. M., Kurahashi, K. \& Jordan, E. (1959). Hereditary defects in galactose metabolism in Escherichia coli. I. Determination of enzyme activities. Proceedings of the National Academy of Sciences of the United States of America 45, 1776-1786.

Katz, L. \& ENGlesberG, E. (1971). Hyperinducibility as a result of mutation in structural genes and self-catabolite repression in the ara operon. Journal of Bacteriology 107, 34-52.

LOBELL, R. B. \& SCHLEIF, R. F. (1990). DNA looping and unlooping by AraC protein. Science 250, 528-532.

Mengin-Lecreulx, D., Floulet, B. \& Van Heijenoort, J. (1983). Pool levels of UDP $N$-acetylglucosamine and UDP $N$-acetylglucosamine-enolpyruvate in Escherichia coli and correlation with peptidoglycan synthesis. Journal of Bacteriology 154, 1284-1290.

Ohwada, T. \& Sagisaka, S. (1987). An immediate and steep increase in ATP concentration in response to reduced turgor pressure in Escherichia coli B. Archives of Biochemistry and Biophysics 259, 157163.

PAYNe, S. M. \& AMES, B. N. (1982). A procedure for a rapid extraction and high-pressure liquid chromatographic separation of the nucleotides and other small molecules from bacterial cells. Analytical Biochemistry 123, 151-161.

Sundararajan, T. A. (1963). Interference with glucerokinase induction in mutants of $E$. coli accumulating gal-1-P. Proceedings of the National Academy of Sciences of the United States of America 50, 463469.

Schwarz, U., Asmus, A. \& Frank, H. (1969). Autolytic enzymes and cell division of Escherichia coli. Journal of Molecular Biology 41, 419429.

Schwarz, V., Golberg, L., Komrower, G. M. \& Holzel, A. (1956). Some disturbances of erythrocyte metabolism in galactosaemia. Biochemical Journal 62, 34-40.

SPRATT, B. G. (1975). Distinct penicillin binding proteins involved in the division, elongation, and shape of Escherichia coli K12. Proceedings of National Academy of Sciences of the United States of America 72, 2999-3003. 
Tanaka, T., Dhavises, G., Taniguchi, M. \& OI, S. (1986). Bulge formation in Escherichia coli induced by L-arabinose under hypertonic conditions with sodium chloride. Agricultural and Biological Chemistry 50, 2663-2665.

Tanaka, T., MuroI, H., Sunada, C., Taniguchi, M. \& OI, S. (1988a). Characterization of L-arabinose-induced bulge formation in Escherichia coli IFO 3545 using L-arabinose-negative mutants. Agricultural and Biological Chemistry 52, 1929-1935.

Tanaka, T., Yano, Y., Taniguchi, M. \& OI, S. (1988b). o-Aminodiphenyl-acetic acid test as a spectrophotometric method for deter- mination of pentose phosphate esters. Agricultural and Biological Chemistry 52, 2097-2099.

Timell, T. E., Glaudemans, C. P. J. \& Currie, A. L. (1956). Spectrophotometric method for determination of sugars. Analytical Chemistry 28, 1916-1920.

YARMOLINSKY, M. B., Wiesmeyer, H., KalCKar, H. M. \& JoRdan, E. (1959). Hereditary defects in galactose metabolism in Escherichia coli mutants. II. Galactose-induced sensitivity. Proceedings of the National Academy of Sciences of the United States of America 45, 1786-1791. 